Copyright (C) 2021 by Academic Publishing House Researcher s.r.o.

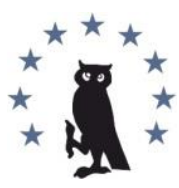

Published in the Slovak Republic

International Journal of Media and Information Literacy

Has been issued since 2016.

E-ISSN: $2500-106 \mathrm{X}$

2021, 6(1): 182-192

DOI: 10.13187/ijmil.2021.1.182

www.ejournal46.com

\title{
YouTube as a New Culture in Indonesia: The Construction of Gender Role in the Lens of the Circuit of Culture
}

\author{
Ida Rosida a, Muhammad Azwar a, * \\ ${ }^{a}$ Universitas Islam Negeri Syarif Hidayatullah Jakarta, Indonesia
}

\begin{abstract}
This study explores the construction of gender roles performed in The Irvandi's YouTube channel. By deploying cultural studies approach and working within the framework of the circuit of culture by Stuart Hall, this study aims to show how gender role is regulated, produced, consumed, and represented, which then constructs Indonesian women's identity. The result shows that the gender role is regulated through religion by which Islamic teachings are applied in her daily life and the social construction rooted within the patriarchal ideology. Next, the video's content is produced as the content creator accepts the gender roles tightly related to the regulation. Further, the video is consumed by its viewer where power, ideology, gender, and social class have shaped each other. Within its consumption, the video reveals the gender stereotyping and brings the effect of empowering women. As an interrelated element, the circuit of culture represents Indonesian women as ideal Muslim women (shaleha). The identity of women in the video is constructed through representation. She constructs her identity as a religious woman and shaleha. Besides, showing viewers where she usually buys home furnishing products indicates that she shows her middle social class. In conclusion, YouTube has become a new culture in Indonesia and has created an Islamic cultural industry as the content is presenting a series of images, practices, and religious values which is marketed especially to Muslim women. Then, this kind of YouTube video is re-strengthening and re-emphasizing the role of women in the family. The differentiation of roles between men and women is reconstructed and reproduced within this online video sharing platform.
\end{abstract} religion.

Keywords: YouTube, culture, media, circuit, Indonesian muslim women, gender role,

\section{Introduction}

The popularity of YouTube in Indonesia has inspired people to produce various content of videos and upload them within this platform. On YouTube, people can share vlogs, music videos, DIY's (Do It Yourself), skits, live shows, and many more (Zanatta, 2017). According to C. Chau (Chau, 2010), YouTube is an online platform in which people can share and broadcast the content. He said that this is a combination of media production and distribution with the features of social networking. This is such an ideal venue to create, connect, collaborate, and circulate something personal. Further, M.L. Khan (Khan, 2017) stated that online behavioral engagement on YouTube is manifested through the way people like, dislike, comment, share, and upload videos. These five actions are seemingly important for the content creator.

\footnotetext{
${ }^{*}$ Corresponding author

E-mail addresses: muh.azwar@uinjkt.ac.id (M. Azwar)
} 
All people can easily become producers for their videos and have a private channel to navigate themselves. It seems that YouTube serves as an attractive platform for amateur content creators and media companies (Burgess, Green, 2018; Xu et al., 2016). The other professions, organizations, and institutions such as politicians, news organizations, education institutes, businesses, music and film artists, and all people from any background are using YouTube (Khan, 2017). This cultural practice, of course, has its purposed. M.L. Khan (Khan, 2017) said that this online platform aims to undergo social interaction, give information, spread the news, and entertain people. Further, P.G. Lange (Lange, 2019) said that sharing videos on YouTube is a way of maintaining social networking. Video could serve as a forum for sharing stories and experiences (Davis et al., 2015).

According to R. Gehl (Gehl, 2009), in this digital age, YouTube highlighted a particular desire as it found a great number of its contents. It has increasingly attracted and tempted people to play with their creativity and become producers for their videos. It is no wonder that hundreds, even thousands, or millions of people worldwide are trying to create content based on their interests, hobbies, and preferences. "Broadcast yourself", however, seems to be the ideal slogan for YouTube (Stiegler, 2009). It is widely known that content creators or commonly called YouTubers, get paid when they reach certain viewers. Plenty of potentials and rewards come with the development of the YouTube channel (Holmbom, 2015). It indicates that capitalism is also playing within this cultural practice. R. Gehl (Gehl, 2009) stated that the evolution of YouTube is somehow inevitable, just like preceding media technologies as it has developed in capitalism. With the temptation of capitalism, it is understandable that YouTube is the fastest-growing site in history (Snickars, Vonderau, 2009).

In Indonesia, people try to engage with this online platform including Indonesian Muslim women. There are many videos created which contents are sharing their personal life, such as doing daily routines, cleaning the house, cooking, taking care of babies, pregnancy moment, childbirth, and many more. On one side, these activities seem to be very private, and people will not know those things to be seen by others. On the other side, people may see these as something common to be performed in public video sharing by which hundreds even thousands of people see their activity. Indonesian women become active participants on YouTube since they have regularly uploaded the videos every day or once a week or at least once a month. Here we see how important it is to share private life, and then it is becoming public consumption. There are plenty of reasons why Indonesian women create videos with such content and upload them to YouTube. They may think that their works on videos are simply about creativity or merely because they love to do so. They may also run their creation for business and earning money. However, we argue that all the activities are not as natural as it is, the works of the content creator on YouTube is an ideological cultural practice. Sharing daily routines such as cleaning the house, cooking, and taking care of babies brings the issues of women, gender, religion, patriarchal ideology, and capitalism. More than that, the actions that the content creator expected, such as like, share, comment, and subscribe have indicated multiple exegeses concerning social, economic, politic, culture, and religion.

One of the YouTube channels which have such content is The Irvandi's Home. This video was published on May 9, 2020, entitled Beres-Beres Rumah \& Bersih Bersih Rumah|Aesthetic Minimalis| Clean up with Me|Cleaning Motivation. An Indonesian Muslim woman presented the video. Within the video, the content creator is stressing her role as a wife and a mother. Here, we see that the text is re-emphasizing the gender role, which tightly relates to Islamic teaching. As the media used to share is YouTube, which is labeling as the fastest-growing company and running the business, it is interesting to see how this kind of cultural practice has participated within the mainstream media. YouTube has become a new platform for Indonesian women to share their domestic matters, mostly in traditional media such as television programs, television advertisements, magazines, and many more. This kind of YouTube channel combines cultural practice, religion, and capitalism. Thus, this becomes the Islamic cultural industry when powers control human activities, including participation on YouTube. As the video highlights the role of women in the family, then gender role is the focus of this research. Considering her active participation on YouTube, which regularly uploads her contents, having 2.449.122 viewers and 22.400 subscribers becoming the reason why this video channel is chosen as the corpus of analysis.

To have a deep understanding on religion in relation to capitalism, the concept of Circuit of Culture by Stuart Hall is used. The Circuit of Culture has five interrelated elements: representation, regulation, production, consumption, and identity. As a circuit, these five elements are flexible on 
what is becoming the first. It can start with the discussion of regulation or production depending on the researcher's being seen first. The circuit of culture stressed those five elements and the interrelated articulations (Cahyo, 2017; Hall et al., 2013; Leve, 2012; Mora et al., 2019).

In exploring the study on YouTube, it is important to see how other scholars were doing such a thing. Here, we highlight three contemporary pieces of research related to this work. First, Lange's research entitles Publicly Private and Privately Public: Social Networking on YouTube, published by Springer in 2019. P.G. Lange (Lange, 2019) analyzed how the content creator on YouTube can develop and maintain social networking. This study showed that circulating and sharing videos on YouTube reflected different social relationships among youth.

Second, the research of Zanatta entitles Understanding YouTube Culture and How It Affects Today's Media published in 2017. In her research, J. Zanatta (Zanatta, 2017) emphasized that YouTube culture has a significant role in shaping society. More than that, it impacted the media as well. Further, she said that YouTube had influenced the younger generation and Millennials because of the history and the evolution of YouTube, the approach of its business and marketing, and the influence of education.

Third, Khan's research entitles Social media engagement: What motivates user participation and consumption on YouTube? It was published in 2017. In his research, M.L. Khan (Khan, 2017) extended the understanding of engagement participation and consumption behavior on YouTube. He revealed that the users of YouTube have various motives such as entertainment motive and social interaction motive for the active participant of YouTube. Meanwhile, it was an information-seeking motive for passive consumption.

Based on the previous works, those studies did not explore the cultural view that is incredibly important to understand the cultural phenomena like the emergence of content creators on YouTube and what is being shared. This study then advances the cultural sight of human behavior on YouTube as they actively upload and share their personal life. Here, by highlighting the language used by the content creator when sharing the daily routines on YouTube. Cultural studies enable a researcher to see the meaning of cultural practices through language. A cultural studies approach provides a lens to understand the meaning of cultural practice as content creators share it on YouTube. Moreover, the circuit of culture emphasizes the production, representation, consumption, regulation, and identity to understand the meaning of cultural practices and to represent the processes by which meaning is constructed within cultures (Hall, 1997). The circuit of culture combines the interrelated elements of representation, production, identity, regulation, and consumption as an inseparable process that investigates cultural phenomena (Hall et al., 2013).

By deploying a cultural studies approach and working within the framework of the circuit of culture, this study aims to explore the multiple interrelated processes involved in the video created by the content creator of YouTube, which tightly related gender, religion, patriarchal ideology, and capitalism. This study addresses the research questions; how does the circuit of culture view the gender role performed on The Irvandi's Home YouTube Channel?

\section{Materials and methods}

This research method is descriptive qualitative by exploring the YouTube video channel named The Irvandi's Home, entitle Beres-Beres Rumah \& Bersih Bersih Rumah|Aesthetic Minimalis|Clean up with Me|Cleaning Motivation. The data analysis is collected by watching the video with a critical understanding of gender roles and focusing on the content creator's language when presenting the daily routines. To explore, analyze and understand more deeply about this cultural practice, we attempt to deploy a cultural studies approach and work within the framework of the circuit of culture by Stuart Hall. The circuit emphasizes the production, representation, consumption, regulation, and identity to understand the meaning of cultural practices and to represent the processes by which meaning is constructed within cultures (Hall, 1997). To investigate the video's content, the circuit of culture then understands the circulated meaning within the culture. The discussion of this research starts with the regulation, followed by the production, consumption, representation, and identity as an interrelated element in the circuit of culture. The circuit reveals the representation of the cultural artifact or practice, the social identity, the production, the consumption, and the mechanism of regulation and distribution (Cahyo, 2017; Mora et al., 2019). 


\section{Discussion}

This study explored five interrelated elements of the Circuit of Culture on a female content creator on YouTube Channel named Irvandi's home. She is a mom of two children, a Muslim woman who wears a hijab, a housewife, and an active participant on YouTube as she regularly uploads the videos on her YouTube channel. In the video's caption, the content creator wrote that she is cleaning the house, children's bedroom, living room, and loving cleaning the furniture from IKEA as the stuff is washable. She added that in this video, she shares her parenting experience for her children. At the end of the caption, she wrote happy watching mom and thanks viewers (The Irvandi's Home, 2020).

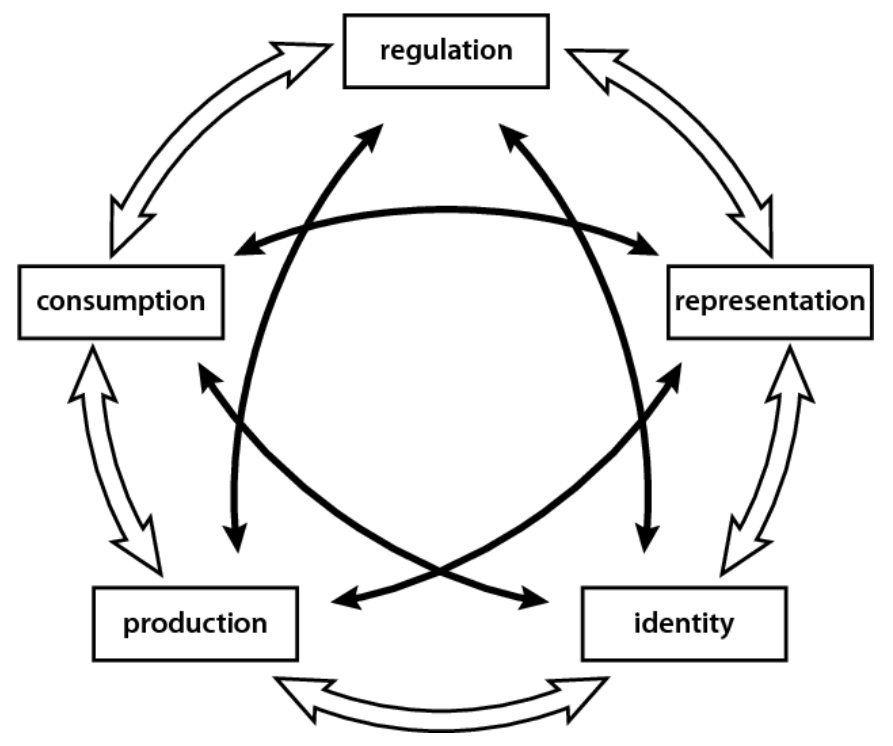

Fig. 1. Circuit of Culture (Hall, 1997)

By focusing on gender role in relation to religion and capitalism, the discussion of the circuit of culture starts with the regulation that inspires the content creator to do their daily routines, then the discussion of production influenced by the regulation. The third discussion is about consumption. Then the consumption which is incredibly important to see the representation. Lastly, based on the representation presented in the video reveal the identity construction of Indonesian Muslim women.

\section{Regulation}

According to Z. Sarabia-Panol and M.D. Sison, regulation consists of formal and informal control that runs social norms, technology, and institutional, including economic, religion, and political systems (Sarabia-Panol, Sison, 2013). For more understanding, formal control alludes to officially authorized regulation instruments such as composed rules, standard operating systems; meanwhile, informal control is unwritten, unofficial, and less objective (Kreutzer et al., 2016).

Talking about women's roles in the family, particularly in Indonesia, is highly related to the religion and social norm, including the differentiation of roles between men and women. For instance, the Quranic verses Surah An-Nissa verse 34, Surah Al-Ahzab verse 33, and some Hadiths written the obligation of women (wife) to her husband. The Islamic teaching attached to the Quranic verse and Hadits is particularly to invite women to be obedient to her husband and do anything based on her husband's permission. In Islam, women are suggested to service husbands, including household and taking care of the babies. The religious teaching is then becoming guidance in every social interaction (Moghissi, 2002).

Next, in Indonesia, the social construction of gender put women in the domestic area. All attributes supposed to be appropriate for women are also influenced by religious tenets, subsequently becoming social norms and cultures. Gender, which is socially and culturally constructed for a very long time, has made women stay with society's social norm. Moreover, gender has made the differentiation of roles, positions, responsibilities, and division of labor between men and women on the nature of women and men, and deemed appropriate according to norms, customs, beliefs, or habits of the community (Molony, 2020). 
Thus, the combination of Islamic teaching and social constructions leads women to produce activity. The content creator is sharing her daily routines concerning her role as a wife a mother. The following text describes how religion and social construction have placed women in domestic matters:

"The plan anyway I want to continue cleaning up the house. Clean up starting from the child's room first, this was the children already finished the condition like this mam. Well, this is your husband's workplace, mam is still a mess, so I will continue to clean up after the nursery. well then this is my living room too mam mess Let's go see the other room, Mam, the chair where there are clothes like that, yes, the child's toys are still there too. Now, this condition there is a husband's wallet, the narration anywhere even though already given a place with me. Well, and then there is the bread that hasn't been put in place, mom, it's a mess. Then in the kitchen, I was still in a mess. I was sleepy, so I didn't clean up first. Now, I want to clean up everything. So now we start Yes, I cleaned the stove first because I want to boil Mam's potatoes for later. Potatoes that want to make potato balls so use cheese mam" (The Irvandi's Home, 2020).

The text above talks about the daily routine of a woman who must clean up the house, including the husband's workspace, taking care of children, and cooking. Those activities are conducted based on the regulation which is internalized in the mind of the women. In Indonesia, religion is the most influential factor for women to run their roles as wives and mothers. Indonesia has the largest Muslim population seeing the conventional interpretations of Islam by emphasizing women's roles as wives and mothers. Also, the content creator is a Muslim woman, and she knows that Islam teaches married women to obey and give services to her husband. Then, cleaning the house, cooking, and taking care of babies is the production by which regulations are attached. The social construction that has been long rooted in Indonesia makes domestic matters solely the women's duties.

Through the concept of regulation applied to this research, this is increasingly acknowledged that Islamic teaching and gender as socially and culturally constructed play an important role in designing and producing the YouTube content that shares Indonesian Muslim women's domestic duties. Moreover, religion and social construction hold power over woman behavior.

\section{Production}

The production within this study means the cultural practice which the content creator presents on her YouTube channel. The video is produced as she has a real situation and real obligation in her family, especially in her role as a wife and mother. The family's role then creates these practices, cleaning the house, taking care of children, cooking, and other domestic duties. As the circuit of culture is highlighted in the interrelated elements within it, this production is influenced by society's regulation and the religion that play an important role in shaping the women in society. In Indonesia, which patriarchal ideology is also strong and the social norm, it has put women in strong thought about becoming a good wife and a good mother. Becoming Shaleha (modest, pious, and obedient to Allah) is ideal for describing Muslim women in Indonesia.

According to Du Gay in A.M. Leve (Leve, 2012), in the late modern societies, the economy and the culture are categorized as a hybrid that is irrevocable. She said what people think of as purely economic processes and practices are cultural phenomena. Here in this study, the cultural practice has the meaning of economic practices. The content creator is trying to produce an economically successful product which the platform is YouTube which is recognized as the fastest growing business today. By saying please press the like button, share, comment, and subscribes represented the aims of creating the video.

"All moms can support me by subscribing like comments and sharing as much as possible must be clicked yes mam the red button that says subscribe has finished then the bell button is activated so that all can get notifications from me when I make a new video Thank you for watching mom see you on my next video. Assalamualaikum" (The Irvandi's Home, 2020).

The content creator produces an economically successful product by which cultural meanings, norms, beliefs, and values are considered. The cultural economy seems the most appropriate to describe the cultural phenomena when YouTube is now becoming a favorite platform to share their activities. The actions ask such as subscribes, likes, comments, and shares by the content creator are solely economic. Gaining more viewers means gaining more benefits for 
the content creator. In this production, economic practices are a cultural practice that is becoming a hybrid (Boxman-Shabtai, 2019).

Thus, the video content on YouTube, which shares women's domestic duties and highlights the women's role in the family, has become the Islamic cultural industry when series of images, practices, religious values are marketed especially to Muslim women. Both the producer (content creator) and the viewers are likely to be active participants either as producers or consumers. Further, this kind of YouTube channel is becoming persuasive media messages that will influence the viewers on women's role in the society, as YouTube is a new media that also has its power to impart the ideological and patriarchal messages (Fourie, 2001). For these reasons, YouTube channel with such video is reconstructed, reproduced, and re-emphasized the existing patriarchal ideologies which have been long rooted in Indonesian culture. Then the Islamic teaching is strengthened its practice in society.

\section{Consumption}

In the article: Within a cultural studies framework, consumption refers to more than the acquisition, use, and divestment of goods and services. Consumption represents a site where power, ideology, gender, and social class circulate and shape one another. Consumption involves studying particular moments, negotiations, representational formats, and rituals in the social life of a commodity. Consumers' consumption of cultural objects can empower, demean, disenfranchise, liberate, essentialize, and stereotype. Consumers are trapped within a hegemonic marketplace (Denzin, 2001; Leve, 2012: 123).

From the understanding of consumption, it is obvious that consumption here is a certain circulation by which power, ideology, gender, and social class have shaped each other. The second key is that the consumer's consumption of one cultural artifact or cultural practice will be empowering, demeaning, revoking suffrage, freeing, essentializing, and stereotyping.

In this study, the notion of consumption refers to the YouTube viewer and their involvement in video-sharing by the content creator through actions such as like, share, subscribe, and the comments available on YouTube. Those who gain the information on the YouTube Channel are considered active consumers interested in such video content.

In this study, power, ideology, gender, and social class shaped each other within consumption recall the patriarchal ideology that put women under the control of men. The patriarchal practice is addressed to women's position in the society, which runs domestic matters only (Asri, Hayati, 2019). This ideology also places women as if she is the only one responsible for any domestic duties. Walby (1989) has shown the two forms of patriarchy, private and public. Private patriarchy refers to the household area or private space such as family and religion. Meanwhile, public patriarchy highlights the wider expansion such as a country. If private patriarchy focuses the power on an individual or a men hand, then the public patriarchy aims to show collective hands' power (Asri, Hayati, 2019).

Further, gender stereotyping is reshaping this video and re-emphasizing women who always stay in the domestic area. This stereotype is also influenced by religion which teaches Muslim women to be shaleha. Then, the social construction leads to the identification of Indonesian women as good Muslim where Islamic teaching is always embraced and considered in their daily actions.

This content empowers women to keep their spirit when doing all domestic duties regarding the key consumption that brings effects such as empowering, stereotyping, and others. This can be seen from the comment of the viewers by responding: "Waalaikumsalam, keep your spirit up, Masya Allah, mom, but why do you clean it up, aren't you sleepy? It's time to rest bun, it's amazing mom, the spirit is really clean". Another comment said keep spirit mom and many more.

Here, the viewers or the consumers keep giving spirit to the content creator, who is always doing domestic duties. Then this indicates the consumption is empowering. Further, as in the whole script of the content creator, she keeps addressing her video for moms. The channel has 2.449.122 viewers and 22.400 subscribers, and most viewers are all women who have the same routines as her. Many of them are giving comments on her video. It means that the content creator has a targeted market on her YouTube Channel. As one of the media, YouTube presents social reality in other media communication (Novianti, Fatonah, 2019). The viewers as a consumer here are essentializing with the women's task as they see on YouTube. Then, the stereotype of a good wife and a good mother also emerges within this study's consumption. 
We can say that the content creator tries to establish a business on YouTube that combines economic and religious motives. She engaged in the creation, labeling, and advertising of the objects, narratives, representations, and performances of Muslim womanhood that combine Islamic teachings and practices with the conceptions of piety and motherhood. B. Gökarıksel and E. McLarney demonstrated that Muslim women had been identified as a segmented market with certain needs and desires, and for the most part, ascribed to an essentialized Muslimness (Gökarıksel \& McLarney, 2010).

\section{Representation}

The exploration of the circuit of culture (regulation, production, and consumption) of the YouTube video brings the representation of Indonesian Muslim women as the content creator presents it on her YouTube channel. Representation is a process by which meaning is produced and share within communities (Hall, 1997). The representation is working through representation systems, thought, and language. To reveal the representation of the YouTube Video by which daily routines of women are shared, seen on the following expression:

"Sometimes I have to take a deep breath first when seeing the mess, mam, but if we want to take the lessons (hikmah); doing this every day, Alhamdulillah, I can train my children for their good habits" (The Irvandi's Home, 2020).

The quotation found the words hikmah and Alhamdulillah indicated that she described herself as a religious person. Becoming a good wife and a good mother also means becoming Islamic. Within the video, the content creator keeps saying Islamic words from the beginning until the end of the video, such as Assalamualaikum, Alhamdulillah, Inshaallah, and many more. The words she said indicated her closeness to religion. Another quotation:

"Alhamdulillah, there is not much dust, if we often clean it like this, so now I clean it more quickly... So, this is the result, Alhamdulillah, it's already neat, it's clean, OK, so I'm even more excited about cleaning in other areas... Well this is the guest room after cleaning. Alhamdulillah, it looks different, just by changing the room decoration a little, I used the flower from the TV shelf and the pot keeps changing, so it looks different, mam yes" (The Irvandi's Home, 2020).

Through the language she used, she tries to describe herself as a religious person who always remembers Allah in every activity. In Islam, these words are called Kalimah Toyyibah or good sayings. Alhamdulillah (all praises to Allah) is suggested to mention when people reach achievement, finish doing things, being healthy, get prosperity and many good things happen in life. Language enables thought, ideas, and feeling to be represented in a culture (Hall, 1997). As a result, this representation produces culture, in this sense, Islamic culture.

Another indication that the content creator is religious found in the following quotation:

"So, if I put the prayer mat here, Mam. Alhamdulillah, this is a small place, but it has a lot of capacity, it can also accommodate 5 as wide as it is Mam, it keeps looking neat, mom does not look like that" (The Irvandi's Home, 2020).

By showing the prayer mate which is used to pray is also becoming a clear sign that she regularly does her obligation as a Muslim by worshiping Allah. The investigation of what the content creator said when delivering her content reveals Indonesian women who are religious and shaleha. Shaleha is frequently addressed to the ideal Muslim women. People's perception of reality is seen through language use (Govender et al., 2014). Here, the perception is the real good wife and mother. As the video is sharing the daily routine of an Indonesian Muslim Woman, it is obvious that a good woman always does the obligation by which it is socially constructed. More than that, religion or Islamic teaching also play an important role in representing Indonesian Muslim women. In this study, the representation is closely tied up with identity.

\section{Identity}

Like the circuit, women's representation through video sharing on YouTube flatform has led to identity construction. Representation is closely related to the contestation area in which power is dominant, both constructing identity and stereotype. S. Hall (Hall, 1997) has shown the stereotyping tends to reduce, irritate, experience, and insulate differences. Political power catch on cultural representation. The power of religion and patriarchal ideology seems to be the strongest element representing Indonesian women's identity.

Dijck (Van Dijck, 2007) argues that the authorship of the YouTube video supports personal agency and creativity. Through the video, both are made and delivered by the owner of the video (McRoberts et al., 2016). The Irvandi's Home, as the content creator, articulates her identity as an Indonesian woman who is religious and shaleha. This is in line with the previous study that 
media represented Indonesian Muslim women as a good wife or shaleha (Rosida, Wulansari, 2017). Further, as one of the media today, YouTube has a great deal in producing meaning (Rosida, 2019). The meaning is produced through the language she used when presenting her video and has shown her identity as an Indonesian Muslim woman.

Besides representing her identity as a good Muslim woman, the social class is also revealed as she mentions brand equity, particularly the shopping mall where she usually buys the furniture and home furnishing:

"So, I want to move the boxes here, Mam, there are boxes for food, so there are also clothes that I bought from IKEA, Mam. Well, this is goat's milk, which is called good fit, before I reviewed this milk, here I will give you the link above, mom" (The Irvandi's Home, 2020).

It is common for a woman to shop the groceries, furniture, and other need. What is being highlighted from the text above is the content creator mention IKEA, the furniture and home furnishing company established first in Sweden. The store, for the first time, opened in Indonesia in 2014. Since its opening, it has gained success as it becomes a reference for Indonesian to shop for furniture and home furnishing. IKEA's main target is family and children, followed the other target such as office, teenagers, and all categories.

Regarding the content creator that mentions IKEA within her video is a kind of articulation of her social class identity. Then, social identity is closely related to where she usually buys pieces of stuff. By shopping in certain brand equity, the content creator impliedly articulates her social class that she is middle social class.

The World Bank reported that Indonesia's economy had grown so fast, and the Indonesian middle class has led the economic growth as the group's consumption has grown, which is half taken from household consumption (The World Bank, 2020). As society has a financial increase, the level of social status has changed. The ability to buy the product and join in consumption is a clear sign of economic growth. Buying a certain product in a certain store indicated the stuff which is affordable for her. The content creator writes in the video description that she is cleaning the house, children's bedroom, living room and she said loving the furniture from IKEA as the stuff is washable. Loving the furniture from the famous brand equity is connected to social class relations. Consuming commodities with specific brand naming is how she constructs her social class identity (Zajda, 2021).

Through the exploration of regulation, production, consumption, and representation, the circuit of culture by which each element is interrelated has led the identity construction. The content creator constructs her identity as an Indonesian Muslim woman from the middle social class within the video. The language she uses when presenting the video helps the researcher reveal the meaning as it shares a thought, ideas, feelings, shopping preferences, and many more.

The analysis of the circuit of culture, which specifically focuses on gender role in Indonesia as presented on YouTube, has given the meaning of the cultural practice when daily routines or all domestic matters are presented in the media. This practice seems to be natural, but in the cultural studies lens, this kind of practice reveals the meaning connected to the power, ideologies, religion, capitalism, and social class (Barker, 2003).

\section{Results}

By using the concept of the circuit of culture, we have explored how the gender role is regulated, produced, consumed, and represented, which then constructs the Identity of Indonesian women as it is performed in The Irvandi's Home YouTube channel. The result shows that the gender role is regulated through religion by which Islamic teachings are applied in every activity that women do. Then, the social construction which rooted within the patriarchal ideology. Next, the gender role is produced by the content creator as she accepted the gender roles which tightly relate to regulation. Further, the video is consumed by its viewer where power, ideology, gender, and social class shaped each other, and the root is the patriarchal ideology and within its consumption. The video reveals the gender stereotyping and brings the effect of empowering women who have the same experience. As an interrelated element, the circuit of culture represents Indonesian women as ideal Muslim women (shaleha). The identity of the woman in the video is constructed through the representation. She constructs her identity as a religious woman and becoming shaleha. Besides, showing viewers where she usually buys home furnishing products indicates that she shows her social class identity. 


\section{Conclusion}

Due to its massive production, YouTube is now becoming a new culture in Indonesia. For women, in particular, this media has become a new platform for them to share their daily life, which brings the issues of women, gender, religion, patriarchal ideology, and capitalism. In Indonesia, both religion and social construction have the strongest role in shaping their identity as women. Shaleha is seemingly appropriate to describe Indonesian women's identity in which Islam and its religious tenet are becoming their consideration for every step they make and for every action they do. Besides, the YouTube channel is a kind of Islamic cultural industry. The content presents the series of images, practices, and religious values marketed, especially Muslim women. Then, this kind of YouTube video is re-strengthening and re-emphasizing the role of women in the family. The differentiation of roles between men and women is reconstructed and reproduced within this online video sharing platform. For further study, this kind of YouTube content can be investigated using other theories such as power relations by Michael Foucault, feminist cultural studies, or feminist media studies.

\section{Acknowledgment}

A high appreciation is mentioned to Sulhizah Wulan Sari, a lecturer at the University of Bina Sarana Informatika, Jakarta, whose expertise is in cultural studies. Thank you for giving comments and suggestions that allowed us to improve this article's clarity and quality. Thanks to The Irvandi's Home YouTube Channel, creating this kind of content enables the researcher to see this practice with a critical understanding of cultural phenomena.

\section{References}

Asri, Hayati, 2019 - Asri, Y., Hayati, Y. (2019). Construction of women's roles in patriarchal culture (Feminist study towards modern Indonesian novels): 43-47. DOI: https://doi.org/ 10.2991/icollite-18.2019.8

Barker, 2003 - Barker, C. (2003). Cultural Studies: Theory and Practice. Sage.

Boxman-Shabtai, 2019 - Boxman-Shabtai, L. (2019). The practice of parodying: YouTube as a hybrid field of cultural production. Media, Culture \& Society. 41(1): 3-20. DOI: https://doi.org/10.1177/0163443718772180

Burgess, Green, 2018 - Burgess, J., Green, J. (2018). YouTube: Online video and participatory culture. John Wiley \& Sons.

Cahyo, 2017 - Cahyo, P.S.N. (2017). Cultural Studies: Perlintasan paradigmatik dalam ilmu sosial. Komunikatif. 3(1): 19-35. DOI: https://doi.org/10.33508/jk.v3i1.1244

Chau, 2010 - Chau, C. (2010). YouTube as a participatory culture. New Directions for Youth Development. 128: 65-74. DOI: https://doi.org/10.1002/yd.376

Davis et al., 2015 - Davis, H., Waycott, J., Zhou, S. (2015). Beyond YouTube: Sharing personal digital stories on a community display. Proceedings of the Annual Meeting of the Australian Special Interest Group for Computer Human Interaction: 579-587. DOI: https://doi.org/10.1145/2838739.2838771

Denzin, 2001 - Denzin, N.K. (2001). The Seventh moment: qualitative inquiry and the practices of a more radical consumer research. Journal of Consumer Research. 28(2): 324-330. DOI: https://doi.org/10.1086/322907

Fourie, 2001 - Fourie, P.J. (2001). Media Studies: Institutions, theories, and issues. Juta and Company Ltd.

Gehl, 2009 - Gehl, R. (2009). YouTube as archive: Who will curate this digital Wunderkammer? International Journal of Cultural Studies. 12(1): 43-60. DOI: https://doi.org/10.1177/1367877908098854

Gökarıksel, McLarney, 2010 - Gökarıksel, B., McLarney, E. (2010). Introduction: Muslim women, consumer capitalism, and the Islamic culture industry. Journal of Middle East Women's Studies. 6(3): 1-18. DOI: https://doi.org/10.2979/mew.2010.6.3.1

Govender et al., 2014 - Govender, N., Rawjee, V.P., Govender, J.P. (2014). Magazines' representation of women and its influence on identity construction: A South African Perspective. Mediterranean Journal of Social Sciences. 5(20): 2278.

Hall et al., 2013 - Hall, S., Evans, J., Nixon, S. (2013). Representation: Cultural representation and signifying practices. The Open University/SAGE. 
Hall, 1997 - Hall, S. (1997). Representation: Cultural representations and signifying practices. Sage.

Holmbom, 2015 - Holmbom, M. (2015). The YouTuber: A Qualitative study of popular content creators. [Electronic resource]. URL: http://urn.kb.se/resolve?urn=urn:nbn:se:umu:diva105388

Khan, 2017 - Khan, M.L. (2017). Social media engagement: What motivates user participation and consumption on YouTube? Computers in Human Behavior. 66: 236-247. DOI: https://doi.org/10.1016/j.chb.2016.09.024

Kreutzer et al., 2016 - Kreutzer, M., Cardinal, L.B., Walter, J., Lechner, C. (2016). Formal and Informal Control as Complement or Substitute? The Role of the Task Environment. Strategy Science. 1(4): 235-255. DOI: https://doi.org/10.1287/stsc.2016.0019

Lange, 2019 - Lange, P.G. (2019). Publicly private and privately public: social networking on YouTube. In Stempfhuber, M., Wagner, E. (eds.), Praktiken der überwachten: öffentlichkeit und privatheit im Web 2.o. Springer Fachmedien: 183-205. DOI: https://doi.org/10.1007/978-3-65811719-1_10

Leve, 2012 - Leve, A.M. (2012). The Circuit of culture as a generative tool of contemporary analysis: examining the construction of an education commodity. In Australian Association for Research in Education (NJ1). Australian Association for Research in Education. [Electronic resource]. URL: https://eric.ed.gov/?id=ED544487

McRoberts et al., 2016 - McRoberts, S., Bonsignore, E., Peyton, T., Yarosh, S. (2016). Do It for the Viewers! Audience engagement behaviors of young YouTubers. Proceedings of the The 15th International Conference on Interaction Design and Children: 334-343. DOI: https://doi.org/ $10.1145 / 2930674.2930676$

Moghissi, 2002 - Moghissi, H. (2002). Feminism and Islam Fundamentalism: The Limits of postmodern analysis. Zed.

Molony, 2020 - Molony, B. (2020). Feminism and gender construction in modern Asia. In A Companion to Global Gender History. John Wiley \& Sons: 525-544. DOI: https://doi.org/ 10.1002/9781119535812.ch32

Mora et al., 2019 - Mora, E., Noia, E., Turrini, V. (2019). Practice Theories and the "Circuit of Culture": Integrating approaches for studying material culture. Sociologica. 13(3): 59-86. DOI: https://doi.org/10.6092/issn.1971-8853/9531

Novianti, Fatonah, 2019 - Novianti, D., Fatonah, S. (2019). Budaya Literasi Media Digital Pada Ibu-Ibu Rumah Tangga. Jurnal Antropologi: Isu-Isu Sosial Budaya. 21(2): 218-226. DOI: https://doi.org/10.25077/jantro.v21.n2.p218-226.2019

Rosida, 2019 - Rosida, I. (2019). Dress Practice in Islamic University: From Regulation to Consumption: 90-93. DOI: https://doi.org/10.2991/icclas-18.2019.24

Rosida, Wulansari, 2017 - Rosida, I., Wulansari, S. (2017). The Representation of Islam Identity on the Commercial TV's Advertisements: 129-131. DOI: https://doi.org/10.2991/icclas17.2018.31

Sarabia-Panol, Sison, 2013 - Sarabia-Panol, Z., Sison, M.D. (2013). International public relations and the circuit of culture: An Analysis of Gawad Kalinga. Asia Pacific Public Relations Journal. 14(1-2): 51-68. [Electronic resource]. URL: https://novaojs.newcastle.edu.au/ apprj/index.php/apprj/article/view/34

Snickars, Vonderau, 2009 - Snickars, P., Vonderau, P. (2009). The YouTube reader. Kungliga biblioteket. [Electronic resource]. URL: http://urn.kb.se/resolve?urn=urn:nbn:se:umu :diva-93619

Stiegler, 2009 - Stiegler, B. (2009). The carnival of the new screen: From hegemony to isonomy. YouTube Reader: 40-59.

The Irvandi's Home, 2020 - The Irvandi's Home (2020). Beres Beres Rumah Sederhana Menarik | Rumah Minimalis | The Irvandishome Vlog. [Electronic resource]. URL: https://www. youtube.com/watch?v=gPmVk5nWOnw

The World Bank, 2020 - The World Bank (2020). Aspiring Indonesia: Expanding the Middle Class. The World Bank. [Electronic resource]. URL: https://www.worldbank.org/ en/news/video/2020/o1/30/indonesia-aspiring-middle-class 
Van Dijck, 2007 - Van Dijck, J. (2007). Television 2.0: YouTube and the emergence of homecasting. Creativity, Ownership and Collaboration in the Digital Age. Cambridge: Massachusetts Institute of Technology: 27-29.

Xu et al., $2016-X u, W . W .$, Park, J.Y., Kim, J.Y., Park, H.W. (2016). Networked cultural diffusion and creation on YouTube: An Analysis of YouTube Memes. Journal of Broadcasting \& Electronic Media. 6o(1): 104-122. DOI: https://doi.org/10.1080/o8838151.2015.1127241

Zajda, 2021 - Zajda, J. (2021). Globalisation, Cultural Identity and Nation-Building. Springer Nature.

Zanatta, 2017 - Zanatta, J. (2017). Understanding YouTube Culture and How It Affects Today's Media [Other]. DOI: https://doi.org/10.33015/dominican.edu/2017.CMS.ST.o3 